\title{
Effect of Desiccants and Herbicides on Germination of Pseudosclerotia and Development of Apothecia of Monilinia vaccinii-corymbosi
}

\author{
K. D. Cox and H. Scherm, Department of Plant Pathology, University of Georgia, Athens 30602
}

\begin{abstract}
Cox, K. D., and Scherm, H. 2001. Effect of desiccants and herbicides on germination of pseudosclerotia and development of apothecia of Monilinia vaccinii-corymbosi. Plant Dis. 85:436-441.

Pseudosclerotia (infected, mummified fruit) are the only source of primary inoculum of Monilinia vaccinii-corymbosi, the causal agent of mummy berry disease of blueberry. Laboratory applications of potential inhibitors of carpogenic germination were made to pseudosclerotia at three distinct developmental stages, i.e., ungerminated pseudosclerotia, pseudosclerotia with emerging stipes, and those with mature apothecia. Potential inhibitors evaluated included soybean oil and ammonium thiosulfate (two desiccants used experimentally as bloom thinners in fruit crops) and diuron and simazine (two commonly used herbicides), each applied in an aqueous suspension with 3\% Latron B-1956 surfactant. Various aspects of carpogenic germination including the percentage of pseudosclerotia that produced stipes or apothecia, the number of stipes or apothecia per pseudosclerotium, the percentage of stipes that developed into apothecia, longevity of stipes and apothecia, and ascospore numbers were assessed. Compared with water, application of ammonium thiosulfate (2\%) and diuron (2\%) reduced stipe and apothecium production when sprayed on ungerminated pseudosclerotia, but these reductions were generally not significantly different from those achieved with Latron B applied alone $(P>0.05)$. The two compounds, however, completely inhibited the development of stipes into apothecia when applied to pseudosclerotia with stipes and caused a $>3$-fold reduction in apothecium longevity when applied to pseudosclerotia with mature apothecia. Application of simazine (2\%) before germination or at stipe emergence resulted in the development of malformed apothecia from which no ascospores were recovered; stipe and apothecium longevity were also reduced. Soybean oil (15\%) and Latron B applied alone had weak or inconsistent effects on most aspects of carpogenic germination of pseudosclerotia, although both compounds, when applied at stipe emergence, significantly reduced ascospore numbers in subsequently formed apothecia. The results suggest that diuron and simazine applied for weed control in commercial blueberry plantings may have beneficial side effects in reducing carpogenic germination of pseudosclerotia. The strong inhibitory effect of ammonium thiosulfate on all aspects of carpogenic germination, along with its value as a nitrogen fertilizer and ancillary herbicide, warrants further evaluation of this compound's performance and economics in the field.
\end{abstract}

Additional keyword: Vaccinium ashei

The discomycete Monilinia vacciniicorymbosi (Reade) Honey causes mummy berry disease, a major problem in commercial blueberry (Vaccinium spp.) production throughout North America $(2,9,17,18)$. The disease results in the formation of fruit mummies (pseudosclerotia) that drop to the ground before or at harvest $(2,9,24)$. The fungus overwinters in these pseudosclerotia on the ground. In late winter or early spring, pseudosclerotia germinate carpogenically to produce apothecia, the only source of primary inoculum. Apothecia release ascospores that infect young vegetative host tissues, causing a leaf and shoot blight (primary infection). Conidia are

Corresponding author: H. Scherm

E-mail: scherm@uga.edu

Accepted for publication 28 December 2000.

Publication no. D-2001-0123-01R

() 2001 The American Phytopathological Society produced on the blighted tissues and then infect open flowers (secondary infection). Flower infection occurs through the stigma and style with subsequent colonization of locules in developing fruit $(12,20,24)$. As infected fruit mature, fungal mycelium in the locules invades the mesocarp and forms a melanized entostroma that encompasses fungal and host elements, thereby forming a pseudosclerotium (3).

Management of mummy berry disease in Georgia focuses on fungicidal protection of susceptible host tissues from infection by the two spore stages $(10,18)$. Currently, no control practices are aimed directly at pseudosclerotia. From an epidemiological viewpoint, however, management tactics targeting pseudosclerotia on the ground could be very effective, given that pseudosclerotia are the only source of primary inoculum of $M$. vaccinii-corymbosi, and that there is only one cycle each of primary and secondary infection per year.

In the past, soil treatments aimed at pseudosclerotia have been used for man- aging mummy berry disease. Calcium cyanamide, applied as a dust, was effective in destroying apothecia and reducing the subsequent shoot blight and fruit infection phases of the disease $(7,8)$. When applied to pseudosclerotia with mature apothecia, the compound caused visible apothecium desiccation and destruction within $10 \mathrm{~min}$ (7). Unfortunately, calcium cyanamide is a caustic chemical that can necrotize young leaves and shoots of blueberry plants. Applications also can lead to unfavorable increases in soil alkalinity. Due to human health hazards associated with the use of calcium cyanamide, the compound is no longer labeled for use on blueberry. Other compounds with a similar mechanism of action but fewer unfavorable side effects may be useful in managing mummy berry disease by destroying pseudosclerotia, stipes, and apothecia. Synthetic (e.g., ammonium thiosulfate) or natural (e.g., soybean oil) desiccants are well known to necrotize plant tissues, a property leading to their experimental use as bloom thinners in fruit trees $(4,13-15,23)$. These compounds, when sprayed onto the soil surface in blueberry plantings, could have similar effects on the succulent stipes and apothecia of $M$. vaccinii-corymbosi produced on overwintered pseudosclerotia. No research evaluating this potential application, however, has been published.

Certain herbicides, when applied to the soil surface, inhibit carpogenic germination in Sclerotinia sclerotiorum, a relative of $M$. vaccinii-corymbosi. For example, the triazine herbicides simazine and atrazine, while stimulating carpogenic germination in S. sclerotiorum, resulted in the production of necrotic, malformed stipes and apothecia $(5,11,16)$. Microscopic inspection of these apothecia revealed that no asci were present in the hymenium (5). Metribuzin (another triazine herbicide) and diuron (a phenylurea herbicide) at high concentrations reduced carpogenic germination in S. sclerotiorum, and the apothecia that did form subsequently were sterile (5). These or similar herbicides, when applied to the soil surface in blueberry plantings during early spring, could affect carpogenic germination of pseudosclerotia of $M$. vaccinii-corymbosi, but few studies have been done to evaluate herbicide effects on this pathogen. Wallace et al. (22) investigated the effect of field applications of several herbicides and reported a reduction in apothecium counts after application of diuron during stipe emergence. Their study, 
however, did not evaluate the effectiveness of applications made at different stages of pseudosclerotial development, nor did it provide data on the dynamics of carpogenic germination or on apothecium fertility in relation to herbicide application. The former information would be particularly important as pseudosclerotia of $M$. vaccinii-corymbosi in Georgia tend to germinate over a long period, thus a single herbicide application would likely act on pseudosclerotia in varying developmental stages.

The objective of this study was to investigate carpogenic germination of individual pseudosclerotia of $M$. vacciniicorymbosi treated with desiccants and commonly used blueberry herbicides. In order to study inhibitory effects more closely, multiple aspects of carpogenic germination (percentage of pseudosclerotia that produced stipes or apothecia, number of stipes or apothecia per pseudosclerotium, percentage of stipes that developed into apothecia, longevity of stipes and apothecia, and ascospore numbers) were assessed after application of the compounds at three distinct developmental stages (to ungerminated pseudosclerotia, at stipe emergence, and to mature apothecia).

\section{MATERIALS AND METHODS}

Potential inhibitors. The compounds tested as potential inhibitors of carpogenic germination were $15 \%$ degummed soybean oil (Omni Tech, Houston, TX), 2\% Thio-Sul (ammonium thiosulfate; Tessenderlo Kerley, Phoenix, AZ), 2\% Diuron 4L herbicide (40\% diuron; Drexel, Memphis, TN), and 2\% Princep $4 \mathrm{~L}$ herbicide $(41.9 \%$ simazine; Novartis, Greensboro, NC). Concentrations of individual compounds were selected to fall within a range previously found effective for bloom thinning or inhibition of carpogenic germination in S. sclerotiorum. All applications were made as aqueous suspensions with 3\% Latron B-1956 surfactant $(77 \%$ modified phthalic glycerol alkyd resin; Rohm and Haas, Philadelphia, PA). Two control treatments (3\% Latron B applied alone and distilled water applied alone) also were included.

Pseudosclerotia. Pseudosclerotia from rabbiteye blueberry ( $V$. ashei $\mathrm{cv}$. Climax) were collected in the field in midDecember (after they had received approximately $400 \mathrm{~h}$ of natural chilling $<7.2^{\circ} \mathrm{C}$ ), transported to the laboratory, rinsed in distilled water containing $0.02 \%$ (vol/vol) Tween 80 to remove residual fruit tissue, and divided into three groups. Pseudosclerotia in group 1 were placed onto the surface of a 1:1 ( $\mathrm{vol} / \mathrm{vol})$ sand-pine bark mix in 10.2-cm diameter clay pots for use in pre-germination treatments (applied before pseudosclerotia showed any signs of carpogenic germination) as described below. The pots, each of which contained 35 pseudosclerotia, were placed in an incubator (referred to as germination chamber hereafter) at 16 to $17^{\circ} \mathrm{C}$ with $>80 \%$ relative humidity and a 14-h photoperiod provided by fluorescent plant growth lights (photon flux density 160 to $180 \mu \mathrm{mol} \mathrm{m} \mathrm{m}^{-2} \mathrm{~s}^{-1}$ ). Pseudosclerotia in group 2 were placed individually in break-apart cell trays $(4.5 \times$ $3.3 \times 5.0 \mathrm{~cm}^{3}$ ) filled with sand-pine bark mix. Trays were placed outdoors in a sand bed on the campus of the University of Georgia, Athens, and irrigated with a fine mist for 15 to 20 min daily. Trays remained outdoors during winter and early spring to allow for carpogenic germination of pseudosclerotia in natural conditions. When individual pseudosclerotia in this group produced stipes or apothecia, they were used in the post-germination treatments as described below. Pseudosclerotia in group 3 were misted with distilled water, placed in sealed plastic bags, and stored at 6 to $8^{\circ} \mathrm{C}$ in the dark until they produced stipes or apothecia, at which time they also were used in the post-germination treatments. Post-germination treatments were made in two groups to obtain a sufficient number of pseudosclerotia at the appropriate developmental stages.

Pre-germination application. This application was made to pseudosclerotia after their chilling requirement for carpogenic germination had been satisfied (19), approximately 6 weeks before visible germination (emergence of stipes) occurred. Suspensions of each of the potential inhibitors or control treatments were applied to experimental units of 35 pseudosclerotia in clay pots (group 1) using an airbrush sprayer (Aztek 320A; Testor, Rockford, IL) at an application rate of approximately $13 \mu \mathrm{l}$ per $\mathrm{cm}^{2}$ of surface area. Pots were arranged in a completely random design with three replications. Following spray application, pots were placed in the germination chamber and pseudosclerotia were monitored for carpogenic germination as described below. The soil surface was kept moist by maintaining the pots in clay saucers and filling the saucers daily with distilled water. The experiment was conducted twice.

Post-germination application to stipes or apothecia. As soon as individual pseudosclerotia in the break-apart cells held outdoors (group 2) had developed stipes 3 to $5 \mathrm{~mm}$ in length, cells containing these pseudosclerotia were removed, transported to the laboratory, and each pseudosclerotium was sprayed with one of the four potential inhibitors or control treatments described above. Similarly, sprays were applied as soon as untreated pseudosclerotia in the cells had produced apothecia with fully expanded discs. This process continued as new stipes or apothecia emerged on previously untreated pseudosclerotia until each treatment was replicated three times with two pseudosclerotia per replication. The experiment was thus a randomized complete block with six treatments and three replications, with groups of two pseudosclerotia as experimental units. Following application, cells containing treated pseudosclerotia were moved into the germination chamber where the soil surface was kept moist by placing the cells in plastic trays and filling the trays with distilled water.

The experiment was repeated with pseudosclerotia from group 3. Groups of six pseudosclerotia with newly emerged stipes or apothecia were transferred onto a sandpine bark mix in individual cells in breakapart cell trays and each pseudosclerotium sprayed with one of the potential inhibitors or control treatments. This process continued over time until each treatment was replicated three times for both stipes and apothecia, with two pseudosclerotia per replication. Following application, cells containing the treated pseudosclerotia were moved into the germination chamber and watered as described above.

Monitoring of stipe and apothecium formation. Using a stereo-microscope, treated pseudosclerotia in the germination chamber were assessed without removing them from the soil surface three times per week and the percentage of pseudosclerotia with stipes or apothecia and the number of stipes or apothecia per pseudosclerotium recorded. For pseudosclerotia treated when stipes were present, the percentage of stipes that developed into mature apothecia, characterized by a fully expanded apothecial disc, was noted. The longevity of treated stipes and apothecia also was recorded. Longevity was defined as the time (in days) from treatment of newly emerged stipes or mature apothecia to the loss of structural integrity (collapse).

Assessment of ascospore production. Ascospore numbers were quantified in a sub-sample of apothecia that developed from previously treated pseudosclerotia. Five days after full expansion of the apothecial disc, apothecia were excised from the pseudosclerotium and placed in 5$\mathrm{ml}$ centrifuge tubes containing $1 \mathrm{ml}$ of distilled water with $1 \%$ ( $\mathrm{vol} / \mathrm{vol})$ Tween 80. Tubes were vortexed for $2 \mathrm{~min}$ and ascospores were counted with the aid of a hemacytometer. Based on measurements of the diameter of the apothecial disc, ascospore numbers were expressed as ascospores per $\mathrm{mm}^{2}$ of disc surface area.

Data analysis. Treatment effects on the percentage of pseudosclerotia that germinated or produced apothecia, the numbers of stipes and apothecia per pseudosclerotium, the percentage of stipes that developed into apothecia, the longevity of stipes and apothecia, and ascospore numbers were analyzed by one-way analysis of variance, with or without block effects as appropriate for the various experiments. Untransformed treatment means were separated with Fisher's protected least significant difference (LSD) test at $P=$ 
0.05. All analyses were carried out using the Statistical Analysis System (SAS Institute, Cary, NC).

\section{RESULTS}

Pre-germination application. Between 19.0 and $27.6 \%$ of the pseudosclerotia treated with water germinated (Table 1), a range typical for pseudosclerotia from rabbiteye blueberry in laboratory conditions (19). Compared with the water control, ammonium thiosulfate and diuron significantly $(P<0.05)$ reduced germination of pseudosclerotia in both trials. The two compounds and soybean oil also lowered the number of stipes per pseudosclerotium consistently and significantly. All treatments, including the Latron B control, significantly reduced the number of apothecia produced subsequently per pseudosclerotium. Ammonium thiosulfate and diuron showed the strongest effect, with $>10$-fold reductions in apothecial numbers in both trials. These reductions, however, were not significantly different from those achieved with Latron B applied alone (Table 1).

All apothecia produced on pseudosclerotia receiving the simazine pregermination treatment appeared necrotic and malformed, with an overgrown, convoluted excipulum (Fig. 1). No ascospores were recovered when five of these malformed apothecia were subject to the extraction procedure described above.

Post-germination application to stipes. Treatment of newly emerged stipes strongly affected the subsequent maturation of stipes into apothecia in both trials (Fig. 2). When treated with water, all stipes developed into apothecia. Fewer stipes matured into apothecia after treatment with Latron B, but this reduction was not statistically significant. A significantly lower percentage of stipes treated with ammonium thiosulfate, diuron, or simazine developed into apothecia compared with the water or Latron B controls. In the case of ammonium thiosulfate and diuron, treated stipes consistently failed to mature into apothecia. Soybean oil was more variable in its effect on apothecial maturation (Fig. 2).

Treatment of pseudosclerotia with newly emerged stipes also affected the longevity of the stipes (Fig. 3), but differences were less pronounced than those related to the maturation of treated stipes into apothecia (Fig. 2). Stipes on pseudosclerotia treated with water persisted for 27 to 29 days on average. This included the period when stipes had developed into mature apothecia. Ammonium thiosulfate, diuron, and simazine significantly reduced longevity compared with water in both trials; how- ever, only ammonium thiosulfate was significantly different from the Latron B control in both trials.

Ascospore numbers in apothecia that developed from treated stipes were significantly lower for all treatments, including the Latron B control, when compared with water (Fig. 4). In the case of simazine and soybean oil, ascospore numbers were always zero. No ascospore numbers were recorded for ammonium thiosulfate and diuron as treated stipes failed to develop into apothecia.

Post-germination application to apothecia. When newly emerged apothecia were treated with water, they persisted for 19 to 29 days on average (Fig. 5). All

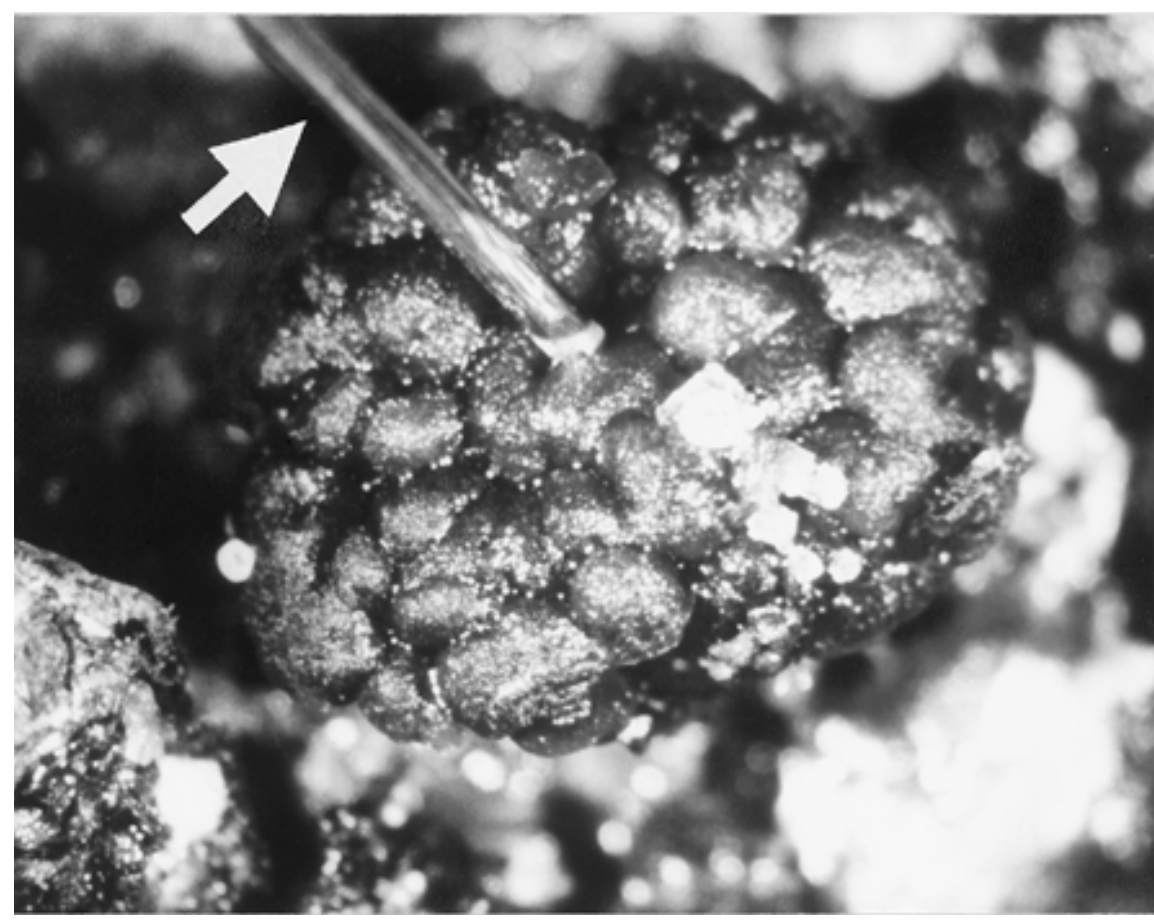

Fig. 1. An apothecium produced after treatment of pseudosclerotia or stipes of Monilinia vacciniicorymbosi with the herbicide simazine. The photograph depicts the surface of a malformed apothecial disc with an overgrown, convoluted excipulum. The apothecium is held in place by a dissecting pin (arrow). Magnification 10x

Table 1. Percentage of pseudosclerotia of Monilinia vaccinii-corymbosi that produced stipes or apothecia, and number of stipes and apothecia per pseudosclerotium, after treatment with desiccants or herbicides ${ }^{\mathrm{w}}$

\begin{tabular}{|c|c|c|c|c|c|c|c|c|}
\hline \multirow[b]{3}{*}{ Treatment } & \multicolumn{4}{|c|}{ Trial 1} & \multicolumn{4}{|c|}{ Trial 2} \\
\hline & \multicolumn{2}{|c|}{$\begin{array}{c}\text { Percentage of } \\
\text { pseudosclerotia }\end{array}$} & \multicolumn{2}{|c|}{$\begin{array}{c}\text { Number per } \\
\text { pseudosclerotium }^{\mathrm{x}}\end{array}$} & \multicolumn{2}{|c|}{$\begin{array}{c}\text { Percentage of } \\
\text { pseudosclerotia }\end{array}$} & \multicolumn{2}{|c|}{$\begin{array}{c}\text { Number per } \\
\text { pseudosclerotium }^{\mathrm{x}}\end{array}$} \\
\hline & With stipes & With apothecia & Stipes & Apothecia & With stipes & With apothecia & Stipes & Apothecia \\
\hline Water control & $27.6 \mathrm{a}$ & $24.8 \mathrm{a}$ & $0.65 \mathrm{a}$ & $0.39 \mathrm{a}$ & $19.0 \mathrm{a}$ & $18.1 \mathrm{a}$ & $0.63 \mathrm{a}$ & $0.50 \mathrm{a}$ \\
\hline Latron B control & $9.5 \mathrm{bc}$ & $6.7 \mathrm{bc}$ & $0.21 \mathrm{bc}$ & $0.15 \mathrm{bc}$ & $13.3 \mathrm{ab}$ & $12.4 \mathrm{ab}$ & $0.36 \mathrm{ab}$ & $0.19 \mathrm{~b}$ \\
\hline Soybean oil + Latron B & $8.6 \mathrm{bcd}$ & $7.6 \mathrm{bc}$ & $0.20 b c$ & $0.14 \mathrm{bc}$ & $6.7 \mathrm{ab}$ & $6.7 \mathrm{ab}$ & $0.19 \mathrm{~b}$ & $0.10 \mathrm{~b}$ \\
\hline ATS $^{y}+$ Latron B & $2.9 \mathrm{~cd}$ & $0.95 \mathrm{c}$ & $0.057 \mathrm{bc}$ & $0.010 \mathrm{c}$ & $2.9 \mathrm{~b}$ & $2.9 \mathrm{~b}$ & $0.076 \mathrm{~b}$ & $0.038 \mathrm{~b}$ \\
\hline Diuron + Latron B & $1.9 \mathrm{~d}$ & $1.9 \mathrm{c}$ & $0.038 \mathrm{c}$ & $0.038 \mathrm{bc}$ & $1.9 \mathrm{~b}$ & $0.95 \mathrm{~b}$ & $0.019 \mathrm{~b}$ & $0.010 \mathrm{~b}$ \\
\hline Simazine $^{\mathrm{z}}+$ Latron B & $12.4 \mathrm{~b}$ & $12.4 \mathrm{~b}$ & $0.23 \mathrm{~b}$ & $0.19 \mathrm{~b}$ & $10.5 \mathrm{ab}$ & $8.6 \mathrm{ab}$ & $0.30 \mathrm{ab}$ & $0.23 \mathrm{~b}$ \\
\hline
\end{tabular}

${ }^{\mathrm{w}}$ Applications were made by spraying pseudosclerotia with an aqueous suspension of the compounds in 3\% Latron B-1956 surfactant before germination. See text for formulations and concentrations.

${ }^{x}$ Each value is the mean of three replications, with 35 pseudosclerotia per replication. Means within the same column followed by the same letter are not significantly different from each other according to Fisher's protected least significant difference test $(P=0.05)$.

y ATS = ammonium thiosulfate.

${ }^{\mathrm{z}}$ All apothecia produced after treatment with simazine were malformed. 
other treatments, including Latron B, significantly reduced longevity of apothecia, with ammonium thiosulfate and diuron resulting in $>3$-fold reductions in longevity in both trials. Reductions in apothecium longevity were similar in magnitude to reductions in stipe longevity (Fig. 3).

\section{DISCUSSION}

Treatment of pseudosclerotia of $M$. vaccinii-corymbosi with desiccants and herbicides affected multiple aspects of carpogenic germination. All compounds showed inhibitory effects at all developmental stages, but the magnitude of these effects differed according to compound, application timing, and the variable measured. Ammonium thiosulfate and diuron had the greatest effect (complete inhibition of development of stipes into apothecia) when pseudosclerotia were treated at the stipe stage. The two compounds also reduced germination and apothecium production when applied to ungerminated pseudosclerotia, and apothecium longevity when applied to mature apothecia. This suggests effectiveness over a range of developmental stages. Previous studies with diuron also found a significant effect on carpogenic germination of pseudosclerotia or sclerotia, but only a single application time was tested. Wallace et al. (22) reported that application of diuron during stipe emergence significantly reduced apothecium numbers in field plots naturally infested with pseudosclerotia of $M$. vacciniicorymbosi. In soil treated with diuron, germination of and subsequent stipe development on sclerotia of S. sclerotiorum were reduced (5). It has been hypothesized that diuron acts by inhibiting respiration in fungi. Diuron at high concentrations reduced the respiration rate of Trichoderma viride, but the effect was transient (6). Thus, despite documentation of significant inhibitory effects by several authors, diuron's mechanism of action in fungi is largely unknown. No previous reports regarding inhibitory effects on fungal plant pathogens are known for ammonium thiosulfate. In higher plants, ammonium thiosulfate acts by a general caustic mech- anism that results in necrosis of young shoots and flowers $(4,15)$.

Similar to ammonium thiosulfate and diuron, treatment of pseudosclerotia with simazine when stipes had emerged reduced the percentage of stipes that developed into apothecia. By contrast, simazine had a limited inhibitory effect on germination of pseudosclerotia. Weak effects of simazine on carpogenic germination also have been reported for sclerotia of S. sclerotiorum $(5,11,16)$. Simazine's most striking effect was the development of malformed apothecia that failed to produce ascospores. In the case of $S$. sclerotiorum, Casale and Hart (5) and Radke and Grau (16) observed that simazine used as a soil treatment consistently resulted in malformed apothecia that revealed no asci in the hymenium. Malformation of apothecia occurred even at $0.25 \times$ the recommended field rate (11). Simazine and other triazine herbicides are photosynthesis inhibitors in higher plants and are believed to interfere with the lightdependent expansion of apothecial discs in S. sclerotiorum (11).

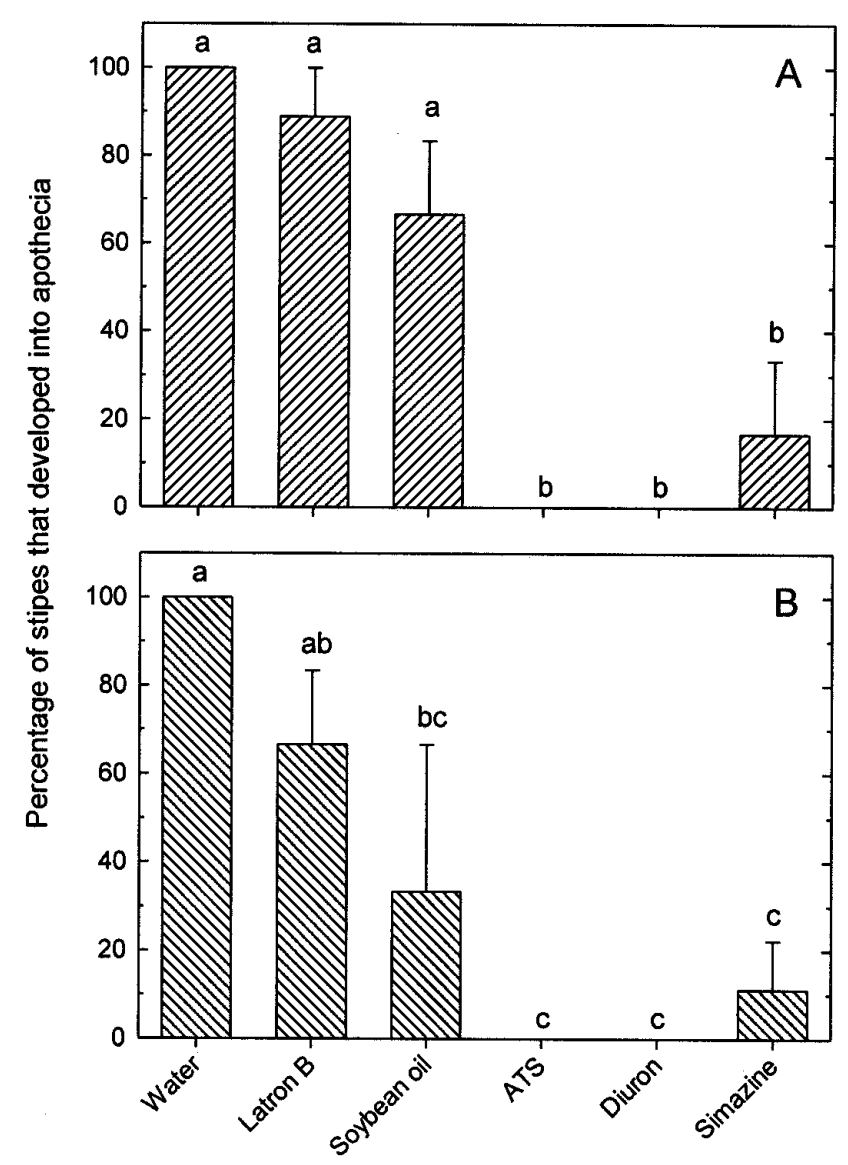

Fig. 2. Percentage of newly emerged stipes of Monilinia vacciniicorymbosi that developed into apothecia after treatment with desiccants or herbicides. Stipes were produced on pseudosclerotia incubated $\mathbf{A}$, outdoors, or $\mathbf{B}$, indoors at 6 to $8^{\circ} \mathrm{C}$ in the dark. ATS $=$ ammonium thiosulfate. Each value is the mean of three replications, with two to six stipes treated per replication. Error bars indicate standard errors. Means with the same letters are not significantly different from each other according to Fisher's protected least significant difference test at $P=0.05$. All apothecia produced after treatment with simazine were malformed.
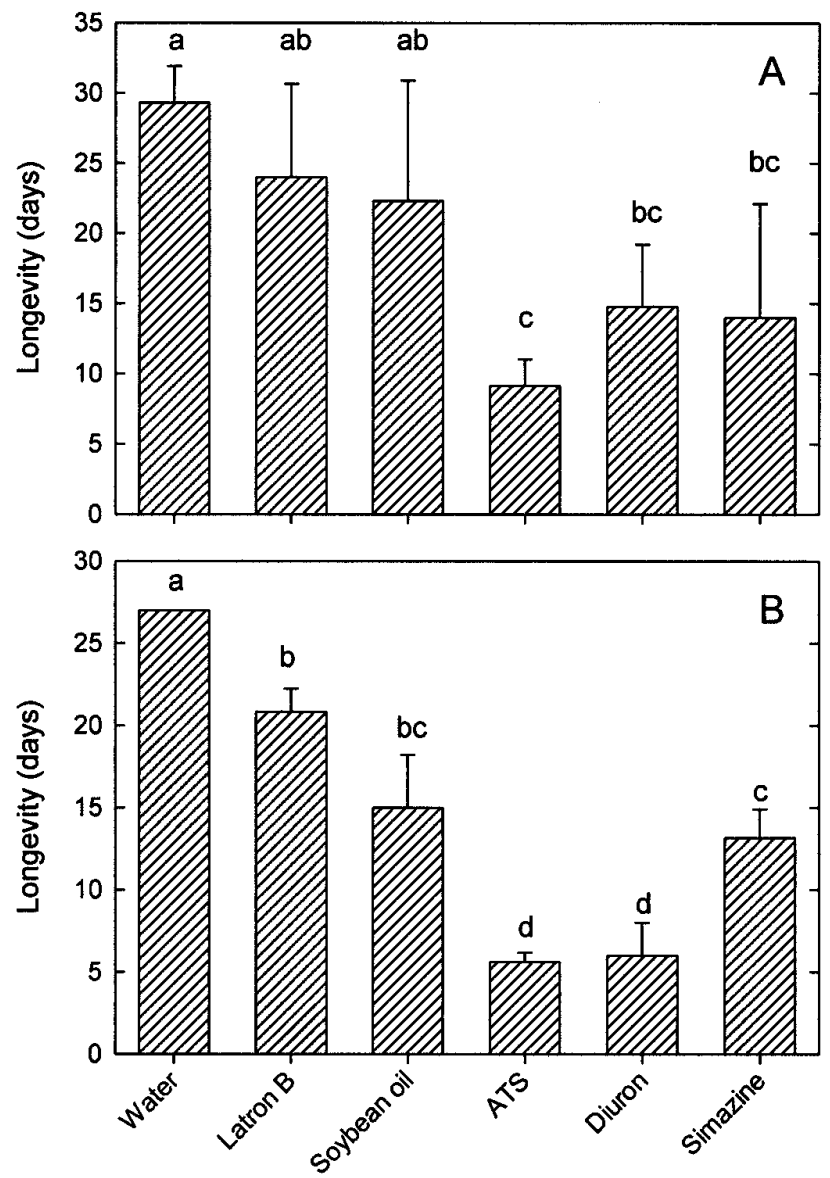

Fig. 3. Longevity of newly emerged stipes of Monilinia vacciniicorymbosi after treatment with desiccants or herbicides. Stipes were produced on pseudosclerotia incubated $\mathbf{A}$, outdoors, or $\mathbf{B}$, indoors at 6 to $8^{\circ} \mathrm{C}$ in the dark. ATS = ammonium thiosulfate. Each value is the mean of three replications, with two to six stipes treated per replication. Error bars indicate standard errors. Means with the same letters are not significantly different from each other according to Fisher's protected least significant difference test at $P=0.05$. 


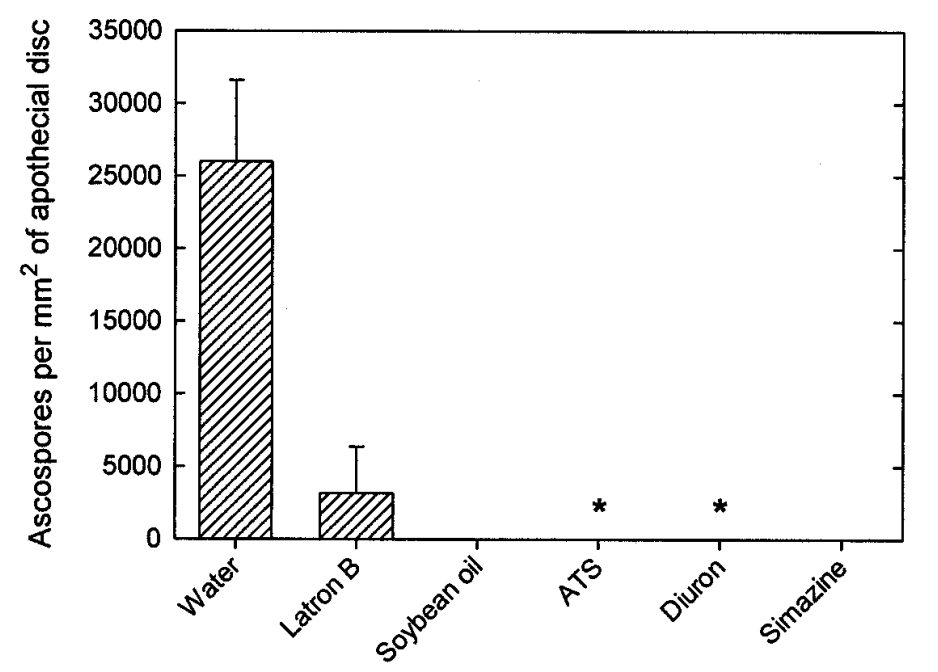

Fig. 4. Number of ascospores produced in apothecia of Monilinia vaccinii-corymbosi that developed after treatment of newly emerged stipes with desiccants or herbicides. ATS $=$ ammonium thiosulfate. Each value is the mean of three to eight apothecia. Error bars indicate standard errors. All apothecia produced after treatment with simazine were malformed. Asterisks indicate treatments for which stipes did not develop into apothecia, thus no ascospore numbers are presented for these treatments.
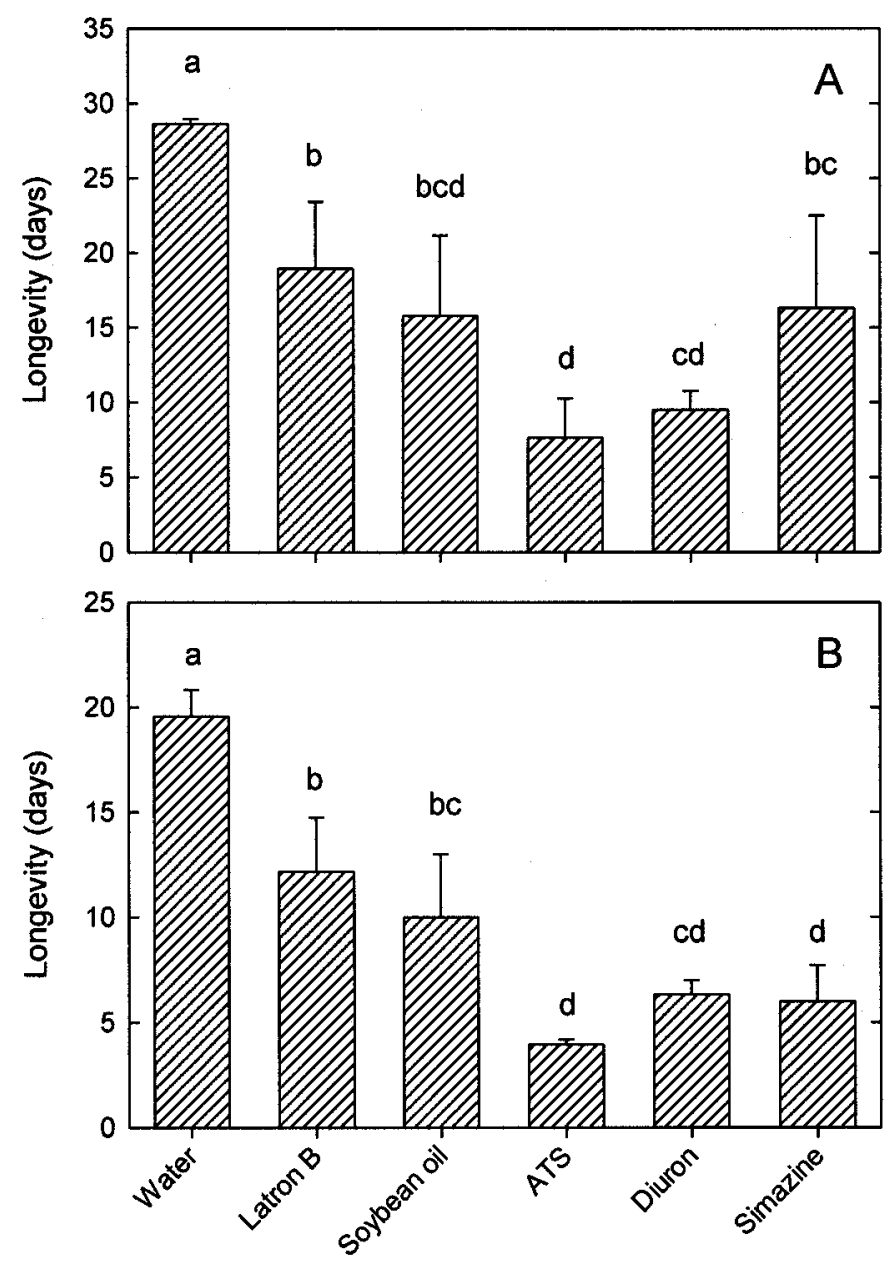

Fig. 5. Longevity of fully expanded apothecia of Monilinia vaccinii-corymbosi after treatment with desiccants or herbicides. Apothecia were produced on pseudosclerotia incubated A, outdoors, or $\mathbf{B}$, indoors at 6 to $8^{\circ} \mathrm{C}$ in the dark. ATS $=$ ammonium thiosulfate. Each value is the mean of three replications, with two to eight apothecia treated per replication. Error bars indicate standard errors. Means with the same letters are not significantly different from each other according to Fisher's protected least significant difference test at $P=0.05$.
Similar to simazine, no ascospores were recovered from apothecia that developed from pseudosclerotia treated with soybean oil at the stipe stage. In contrast to simazine, however, the reduction in spore production was not associated with abnormal apothecial morphology, suggesting a different mechanism of action. Soybean oil was intermediate or inconsistent in its effects on other aspects of carpogenic germination of pseudosclerotia. In fruit crops, oils such as soybean oil thin flower buds and delay bloom by restricting gas exchange (14). How soybean oil acts in fungi is unknown.

Latron B applied alone to some extent reduced the number of apothecia produced per pseudosclerotium and apothecium longevity. Nevertheless, the compound strongly reduced ascospore production when applied at stipe emergence. As all other compounds were mixed with Latron $B$, their effects could have been confounded. However, ammonium thiosulfate, diuron, or simazine combined with Latron $B$ had significantly greater effects on most variables measured than Latron B alone, suggesting that the observed effects were not simply due to the surfactant.

Most previous studies on the effect of herbicides and other soil treatments on carpogenic germination of pseudosclerotia or sclerotia of plant-pathogenic fungi provided only data on final numbers of apothecia, without detailed assessments such as the percentage of stipes that developed into apothecia or stipe and apothecium longevity $(5,16,21,22)$. Similarly, previous studies generally involved a single treatment applied either before or during germination. In the present study, the use of three discrete application timings based on the stage of carpogenic germination allowed for a wider window of time to be examined, which could provide useful information for application timing in field tests on the destruction of initial inoculum of $M$. vaccinii-corymbosi.

As the present study was primarily laboratory based, several aspects must be considered when extrapolating results to the field. Diuron and simazine, both of which strongly affected certain aspects of carpogenic germination, are labeled and commonly used for weed control in commercial blueberry production $(10,18)$. Both herbicides are applied in early spring before weed emergence, which would coincide with the presence on the ground of ungerminated pseudosclerotia or pseudosclerotia at the stipe stage. Application rates of both herbicides in our study (calculated as 0.10 and $0.11 \mu \mathrm{l}$ a.i. $\mathrm{cm}^{-2}$ for diuron and simazine, respectively) were 6to 7-fold higher than those recommended in the field in blueberries (1.4 and 2.0 liters a.i. $\mathrm{ha}^{-1}$ ). In practice, application of such high rates would be uneconomical, suggesting limited potential of herbicide sprays targeted specifically at pseudoscle- 
rotia of M. vaccinii-corymbosi. However, side effects on carpogenic germination of the two herbicides applied at lower rates for standard weed control are likely (11) and could help explain variations in apothecial numbers observed in blueberry plantings with similar numbers of pseudosclerotia (H. Scherm, unpublished data).

For ammonium thiosulfate, which also had a strong inhibitory effect on most aspects of carpogenic germination, the rate tested $\left(0.26 \mu \mathrm{cm}^{-2}\right)$ was approximately 2 to 4-fold lower than the recommended field rate for tree and vine crops (46.8 to 93.5 liters $\mathrm{ha}^{-1}$ ). Thus, applications at the recommended rate in the field would be expected to exert a similar inhibitory effect on carpogenic germination of $M$. vaccinii-corymbosi as observed in the present study, assuming good coverage could be obtained. Additional features of ammonium thiosulfate that could increase the compound's economic appeal are its value as a nitrogen fertilizer and a potential post-emergence broadleaf herbicide (1). These aspects warrant further performance and economic evaluations in field trials.

\section{ACKNOWLEDGMENTS}

Research was supported by the Hatch Act and State of Georgia funds. We thank C. Mims, A. Savelle, and J. Williams-Woodward for reviewing an earlier version of the manuscript.

\section{LITERATURE CITED}

1. Agamalian, H. 1984. Post-emergence weed control in crucifers with nitrogenous fertilizers. Proc. West. Soc. Weed Sci. 37:57-59.

2. Batra, L. R. 1983. Monilinia vacciniicorymbosi (Sclerotiniaceae): Its biology on blueberry and comparison with related species. Mycologia 75:131-152.

3. Batra, L. R. 1991. World Species of Monilinia
(Fungi): Their Ecology, Biosystematics, and Control. Mycological Memoir 16. J. Cramer, Berlin.

4. Byers, R. E., and Lyons, C. G. 1985. Peach flower thinning and possible sites of action of desiccating chemicals. J. Am. Soc. Hort. Sci. 110:662-667.

5. Casale, W. L., and Hart, L. P. 1986. Influence of four herbicides on carpogenic germination and apothecium development of Sclerotinia sclerotiorum. Phytopathology 76:980-984.

6. Davis, D. E., Pillai, C. G. P., and Truelove, B. 1976. Effects of prometryn, diuron, fluometuron, and MSMA on Chlorella and two fungi. Weed Sci. 24:587-593.

7. Fulton, R. H. 1958. Controlling mummy berry disease of blueberries by soil treatment. Q. Bull. Mich. State Coll. Agric. Exp. Stn. 40:491-497.

8. Fulton, R. H., and Grigsby, B. H. 1952. The effect of several soil treatments on mummy berry disease of blueberries in Michigan. Q Bull. Mich. State Coll. Agric. Exp. Stn. 34:297-302.

9. Honey, E. E. 1936. North American species of Monilinia. I. Occurrence, grouping, and lifehistories. Am. J. Bot. 23:100-106.

10. Horton, D. L., Ellis, H. C., Scherm, H., Copes, W., Amis, A., MacDonald, G., Krewer, G., and NeSmith, S. 1998. 1999 Commercial Blueberry IPM and Culture Guide. Cooperative Extension Service, University of Georgia, College of Agricultural and Environmental Sciences, Athens.

11. Huang, H. C., and Blackshaw, R. E. 1995. Influence of herbicides on the carpogenic germination of Sclerotinia sclerotiorum sclerotia. Bot. Bull. Acad. Sinica 36:59-64.

12. Milholland, R. D. 1977. Sclerotium germination and histopathology of Monilinia vacciniicorymbosi on highbush blueberry. Phytopathology 67:848-853.

13. Moran, R. E., Deyton, D. E., Sams, C. E., and Cummins, J. C. 2000. Applying soybean oil to dormant peach trees thins flower buds. HortScience 35:615-619.

14. Myers, R. E., Deyton, D. E., and Sams, C. E. 1996. Applying soybean oil to dormant peach trees alters internal atmosphere, reduces respi- ration, delays bloom, and thins flower buds. J. Am. Soc. Hort. Sci. 121:96-100.

15. Olien, W. C., Miller Jr., R. W., Graham, C. J, Taylor, E. R., and Hardin, M. E. 1995. Effects of combined applications of ammonium thiosulphate and fungicides on fruit load and blossom blight and their phytotoxicity to peach trees. J. Hort. Sci. 70:847-854.

16. Radke, V. L, and Grau, C. R. 1986. Effects of herbicides on carpogenic germination of Sclerotinia sclerotiorum. Plant Dis. 70:19-23.

17. Scherm, H., and Copes, W. E. 1999. Evaluation of methods to detect fruit infected by Monilinia vaccinii-corymbosi in mechanically harvested rabbiteye blueberry. Plant Dis. 83:799-805.

18. Scherm, H., Horton, D. L., NeSmith, D. S. Krewer, G., and Savelle, A. T. 1999. Georgia blueberry pest management survey. Pages 37 45 in: Blueberry Research at the University of Georgia: 1999 Annual Research Update. D. S. NeSmith, ed. Research Report 662, University of Georgia, College of Agricultural and Environmental Sciences, Athens.

19. Scherm, H., Savelle, A. T., and Pusey, P. L. 2001. Interactions between chill-hours and degree-days affect carpogenic germination in Monilinia vaccinii-corymbosi. Phytopathology 91:77-83.

20. Shinners, T. C., and Olson, A. R. 1996. The gynoecial infection pathway of Monilinia vaccinii-corymbosi in lowbush blueberry (Vaccinium angustifolium). Can. J. Plant Sci. 76:493-497.

21. Teo, B. K., Verma, P. R., and Morall, R. A. A. 1992. The effects of herbicides and mycoparasites at different moisture levels on carpogenic germination in Sclerotinia sclerotiorum. Plant Soil 139:99-102.

22. Wallace, D. B., MacHardy, W. E., and Meander, E. M. 1976. Control of mummy berry of highbush blueberry in New Hampshire. Plant Dis. Rep. 60:97-101.

23. Webster, A. D., and Hollands, M. S. 1993. Thinning 'Victoria' plums with ammonium thiosulphate. J. Hort. Sci. 68:237-245.

24. Woronin, M. 1888. Über die Sclerotienkrankheit der Vaccinieen-Beeren. Mém. Acad. Imp. Sci. St.-Pétersbourg (VIIe Série) 36:1-49. 